\title{
POWER CABLE DEFECTS AND THEIR INFLUENCE ON ELECTRIC FIELD DISTRIBUTION IN POLYETHYLENE INSULATION
}

\author{
Kucheriava I.M. \\ Institute of Electrodynamics, National Academy of Sciences of Ukraine, \\ pr. Peremohy, 56, Kyiv, 03057, Ukraine. E-mail: rb.irinan@gmail.com
}

The paper studies the cable degradation mechanisms and electric field distributions in the polyethylene insulation of power cables with typical defects at macroscopic level including crack and numerous air bubbles in the insulation, protrusion of inner semiconducting layer, its air gapping with cable insulation and interruption along the cable conductor, holes in outer semiconducting layer, its delamination from copper shield as well as small air hole in the shield owing to corrosion. The three-dimensional computer modeling and analysis of electric field distributions are carried out in the chosen region of the cable containing the defects. The patterns of the distributions and local field enhancement in the vicinity of the defects are shown. The effect of defects on electric field in the polyethylene cable insulation is revealed. References 11, figures 5 .

Key words: polyethylene insulation, typical power cable defects, local electric field enhancement, three-dimensional computer modeling.

Introduction. The uninterrupted operation of the electric power transmission and distribution systems needs high reliability and operating longevity of power cable lines. The reliability, no-failure operation and long service life of power systems depend greatly on the quality of cables, on their materials, manufacturing, design, transportation, installation, jointing and operating conditions. During the last decades the power cables with cross-linked polyethylene (XLPE) insulation are extensively used throughout the world. At present XLPE insulated cables are preferred cables for high and extra high voltage power lines (up to $110-500 \mathrm{kV})$. In this connection the high quality and required reliability of the cables are needed to be ensured.

First of all, the failure of power cables is due to failure and destruction of their insulation. The inhomogeneity of its structure increases for more high voltage cables with more thick polyethylene insulation. The defects and imperfections of the insulation and other cable elements (fig. 1) are mainly responsible for the initiating water and electrical trees, partial discharge activity, functionality, deterioration, aging, electric strength of the insulation as well as for reliability and service life of power cables $[2-4,8]$. This affirms the importance of theoretical and practical investigation of typical power cable defects to develop proper technology solutions for economically substantiated reduction in size and number of the defects.

Starting from the center, XLPE insulated cable consists of current carrying conductor, conductor shield (or inner semiconducting layer), polyethylene insulation, insulation shield (outer semiconducting layer), metallic (copper) shield and non-metallic jacket (fig. 1, $a$ ).

The conductor is the most necessary element of cable. It carries the electrical current and has two designs for high-voltage cables, namely round stranded or segmental Milliken stranded conductor as in fig. 1, $a$.

The inner semiconducting layer is a screen on conductor and an interface between the conductor and the insulation. It prevents electric field concentration in the insulation and smoothes out the conductor surface. The outer semiconducting layer is a screen on insulation. It gives smooth interface between the insulation and the copper shield. As a rule, the materials of the semiconducting layers have a higher conductivity than polyethylene cable insulation. The protrusions of the semiconducting layers into the insulation, delaminations and interruptions of the layers along with holes inside them are the main defects of these cable elements.

The insulation of power cables needs separate attention. According to fig. 1, the polyethylene insulation includes both volume defects (such as conducting and non-conducting impurities, air voids and cracks) and surface defects owing to the roughness and imperfections of adjacent semiconducting layers. The voids, contaminants in the insulation, its gapping with the layers and other design and manufacturing defects result in the stress and electric field concentrations within the cable. For example, the micro-sized inclusions and water-filled voids cause field enhancement, initiation of water tree growth, resulting in accelerated insulation aging and premature failure of the cable [2]. The defects are the initiation sites for water treeing because of increased local electric field. Water trees occur in the presence of water in the insulation and are accompanied with partial discharges which can deteriorate the insulation and accelerate its failure. The discharges are

(C) Kucheriava I.M., 2017 

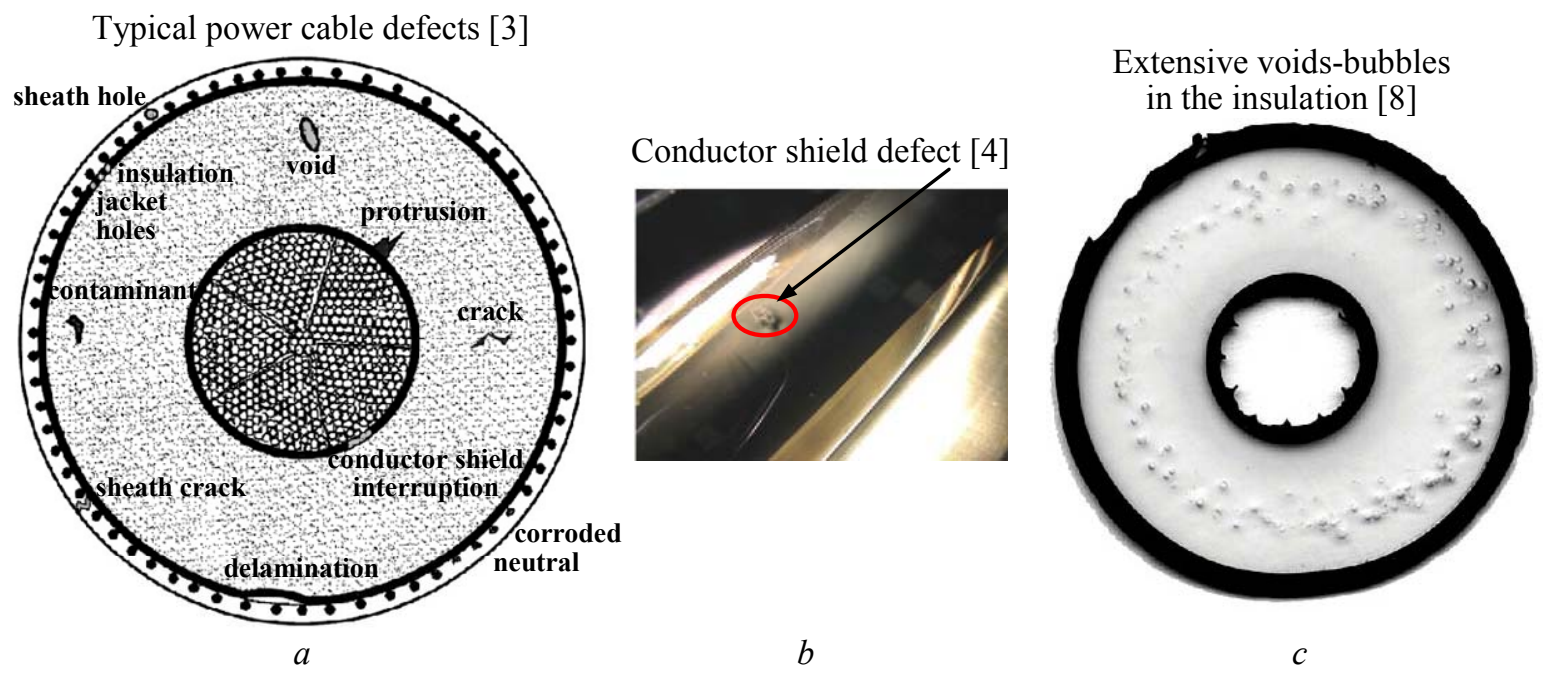

Fig. 1

usually generated from voids, cracks, cavities and near the protrusions, cuts, delaminations, contaminations in the insulation when the local electric field exceeds the dielectric strength of the insulating material.

In general, the degradation mechanisms of XLPE insulation are divided into electric, electromechanical, thermal and partial discharge mechanisms $[2,3,5,9]$.

The micro-protrusions of semiconducting layers into XLPE insulation, conducting and dielectric micro-sized inclusions, water cavities in the insulation are detected and studied in article [10]. As shown in [10], these defects are the origins of water and electrical trees, lead to the destruction of the insulation and subsequent failure of the cable.

The two- and three-dimensional modeling of electric field distribution, temperature and electromechanical stresses in the cable polyethylene insulation with volume and surface defects (air and water voids, water treeing, micro-protrusions into the insulation) is carried out in works [5-7,9]. The degree of electric field inhomogeneity near the imperfections is evaluated too.

The metallic (copper) shield is placed over the outer semiconducting layer and nullifies the electric field outside the cable. The second its function is to form a barrier for moisture penetration in the cable insulation. The shield can suffer mechanical damage during installation and corrosion in service. Corrosion is a problem for metallic shield. It can arise and be accelerated at the interface between the metal and adjacent cable elements due to water ingress and aggressive environment (contact with corrosive chemicals, fertilizers, etc.).

The non-metallic jacket provides protection of the cable against external mechanical, thermal, chemical effects and moisture penetration.

The power cables age as time progresses. They age, deteriorate and fail depending on many factors such as electrical, thermal, environmental, mechanical factors, factor of time, imperfect XLPE insulation [3]. The typical power cable defects are shown schematically in fig. 1, $a$. It is important that the defects can grow with time.

The cable defects are categorized in the following areas:

- manufacturing imperfections (voids, contaminants, protrusions, cracks, eccentricity, etc.);

- defects of construction and installation including mechanical defects (tension, bending, compression, external damages, vibration, etc.);

- operational defects (due to moisture ingress, treeing, system voltage changes, overload currents, overvoltages, excessive heating, low/high ambient temperature, corrosion, radiation, etc.).

All types of the defects acting singly or synergistically can lead to the changes in materials of the insulation system, their properties and eventually cause accelerated ageing of XLPE insulation and failure or breakdown of the cables.

The purpose of the present work is to study electric field distribution in the insulation system of XLPE insulated power cable with typical macroscopic defects namely cracks and extensive voids-bubbles (fig. 1, c) in the insulation, interruption of inner semiconducting layer along the cable conductor, protrusion of the layer into the insulation (in accordance with fig. 1, $a, b$ ), air gap between the layer and the cable insulation, delamination of outer semiconducting layer from metallic shield, holes in the layer and small air hole in the copper shield because of its corrosion. The single conductor XLPE insulated $110 \mathrm{kV}$ power cable is 
considered. The three-dimensional modeling is performed in the volume region of the cable containing the defects. The electric field distributions are computed in professional code Comsol [1] using finite-element method.

Model for computations. The model is presented in three-dimensional Cartesian coordinate system. The computational region of electric problem includes polyethylene insulation, semiconducting layers and copper shield in the half part of the cable (fig. 2,a). The conductor and jacket of the cable are left out of account.

Under quasi-static approximation (at $50 \mathrm{~Hz}$ frequency) the electric potential $\dot{\varphi}$ is obtained from the following equation:

$$
\nabla \cdot\left(\sigma+j \omega \varepsilon_{o} \dot{\varepsilon}_{r}\right) \nabla \dot{\varphi}=0,
$$

where $\sigma$ is the conductivity of the material; $\dot{\varepsilon}_{r}$ is the complex relative permittivity; $\varepsilon_{0}=8,85 \cdot 10^{-12} \mathrm{~F} / \mathrm{m}$ is the vacuum permittivity; $j$ is the imaginary unit; $\omega$ is the angular frequency.

The space charge is put out of account in the model. The non-identical values of $\dot{\varepsilon}_{r}$ and $\sigma$ are defined for different cable elements.

The next boundary conditions are specified. The condition $\dot{\varphi}=U_{m}$ (where $U_{m}$ is the peak value of phase voltage) is set on conductor surface. The null electric potential $(\dot{\varphi}=0)$ is prescribed on the surface of copper shield. The condition of electric insulation $\mathbf{n} \cdot \mathbf{J}=0$ ( $\mathbf{n}$ is the unit external normal; $\mathbf{J}$ is the total current density) is defined on the other boundaries.

The electric intensity is determined from numerical solution of the problem by expression: $\dot{\mathbf{E}}=-\nabla \dot{\varphi}$.

Computer results and discussion. The computer modeling is realized for $110 \mathrm{kV}$ XLPE insulated cable with conductor cross-section area of $500 \mathrm{~mm}^{2}$ (conductor diameter of $25.2 \mathrm{~mm}$ ) and $16 \mathrm{~mm}$ insulation thickness. The cross-section area of cable copper shield is $35 \mathrm{~mm}^{2}$ (its thickness is equal to $4 \mathrm{~mm}$ ). The thickness of each semiconducting layer is $1 \mathrm{~mm}$.

In the model the conductivity of polyethylene insulation is set to be $\sigma_{1}=10^{-15} \mathrm{~S} / \mathrm{m}$, the conductivity of semiconducting layers is $\sigma_{2}=10^{-7} \mathrm{~S} / \mathrm{m}$. The relative dielectric permittivity of the materials is $\varepsilon_{1}=$ $=\varepsilon_{2}=2,3$.

The computational region contains the half part of the cable with defects (fig. 2,a). Taking into account the cable symmetry and preset boundary conditions, it means that the same defects exist in the other symmetric part of the cable. This may be assumed because the increased electric field takes place only in the local zones near the defects.

The finite element mesh is generated as shown in fig. $2, b$. The mesh resolution is increased at the location of the defects, especially at their sharp tips and at the interfaces with cable elements.

The computed electric field distribution in the insulation without defects as well as the color legend with electric intensity values is presented in fig. 2, $c$ for subsequent comparison with different types of defects (figs. 3-5). Note that the field distribution in the insulation without any defects can be calculated not only numerically but also analytically using formula from [11].

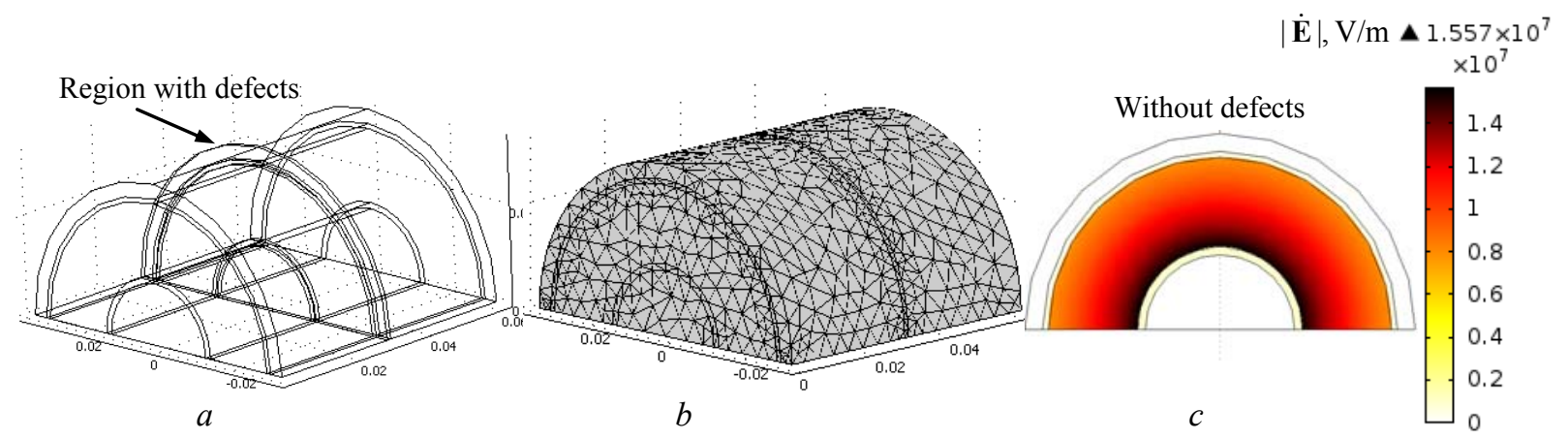

Fig. 2 


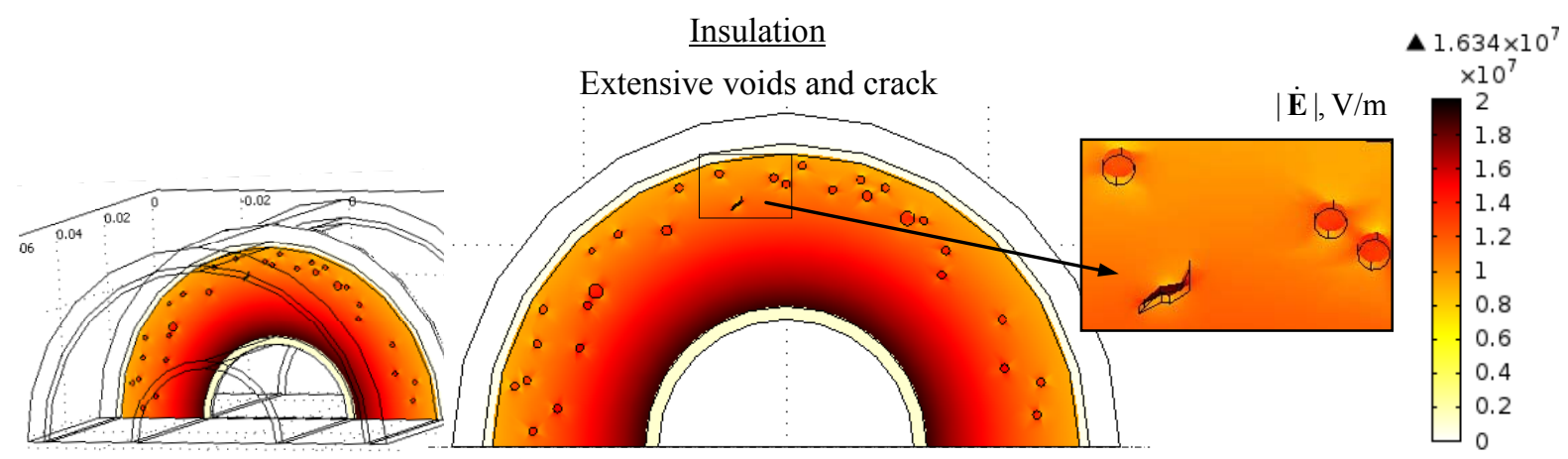

Fig. 3

Fig. 3 gives the pattern of electric field in the polyethylene cable insulation containing extensive voids-bubbles and crack in compliance with fig. 1, $a, c$. As seen, the electric intensity increases at the sites of the defects and the interaction of neighboring voids is taken place (fig. 3 at the right). In the case under consideration, the voids are in the part of the insulation where leaving out of account the defects, the electric field is equal to $|\dot{\mathbf{E}}|=8-9 \mathrm{kV} / \mathrm{mm}$ according to fig. 2, $c$. Then the degree of field inhomogeneity for the insulation with voids-bubbles and crack near the outer semiconducting layer (fig. 3 ) is evaluated by

$$
k=\frac{|\dot{\mathbf{E}}|_{\max }}{|\dot{\mathbf{E}}|_{a v}}=\frac{1.634 \cdot 10^{7}}{8.5 \cdot 10^{6}}=1.92 .
$$

The various positions of the voids within the insulation in the vicinity of the cable conductor are computed too. For them the coefficient of inhomogeneity is $k \approx 2.4$. In the general case this coefficient depends on the shape and spatial location of the defects in the insulation.

The protrusion of the inner semiconducting layer into the insulation (fig. 4, $a$ ), interruption of the layer (fig. 4, $b$ ) and its air gapping (fig. 4,c) are dangerous in the context of increased electric intensity (as compared to fig. 2,c). As shown, such defects contribute to the reduction of dielectric strength of the insulating material. The peak value of electric field takes place at the sharp tip of the protrusion (fig. 4, a). This is a weak area of the insulation close by the cable conductor.

The delamination of outer semiconducting layer causes the increase of electric intensity both at the interface with the insulation and within the layer (fig. 5, $a$ ). The field is maximum at the sites of the layer separation as shown at the top of fig. $5, a$.

The electric field distributions in the outer semiconducting layer without any defects, with several holes and with small air hole at the interface with copper shield owing to its corrosion are illustrated in fig. $5, b$ and $c$. In the last case the field is shown only in the semiconducting layer excluding the air gap appearing in the layer. As revealed by modeling, the defects have no direct influence on electric field in the insulation but taking into account the time factor and possible generation of electrical discharges, the defects under study can cause erosion of the semiconducting layer and subsequently the cable insulation.

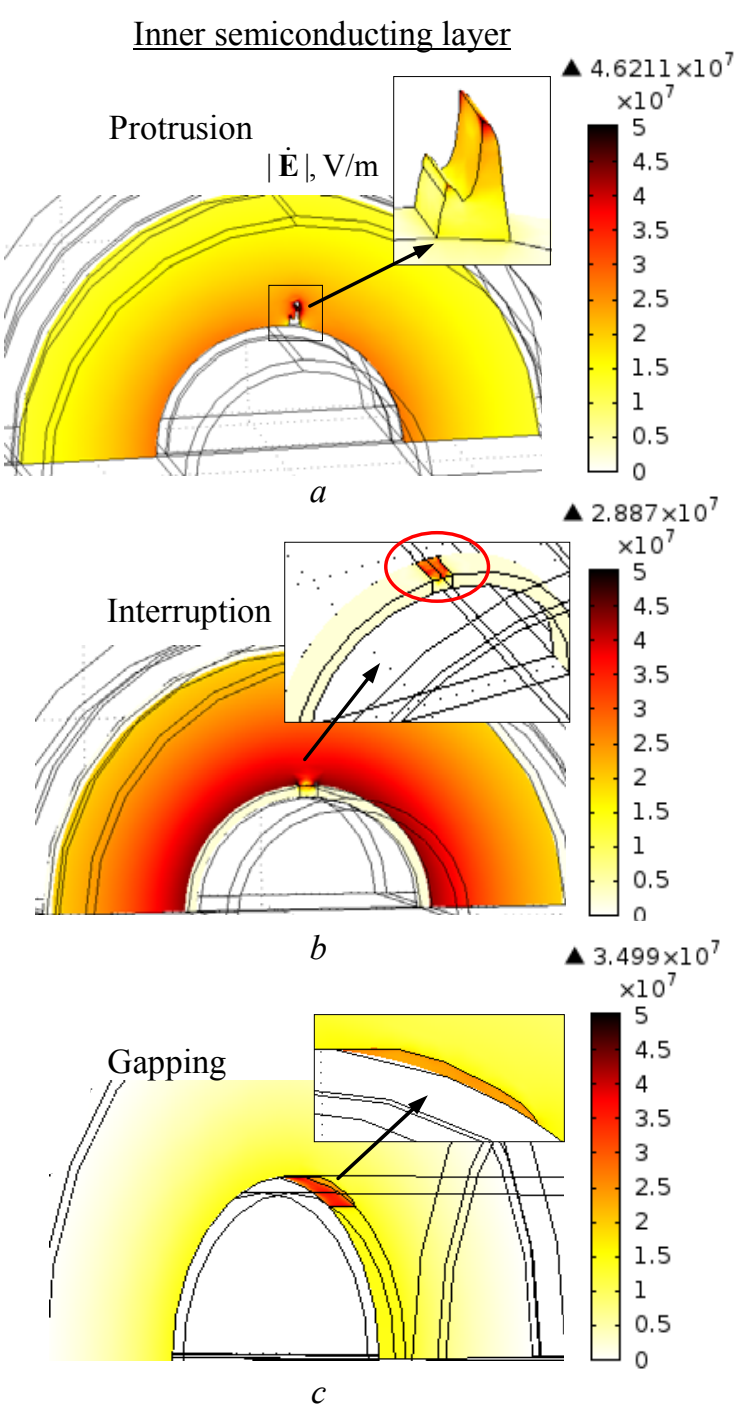

Fig. 4

As found by numerical modeling, the availability of the macroscopic cracks inside the cable metallic shield has no effect on electric field distribution in the polyethylene insulation. 


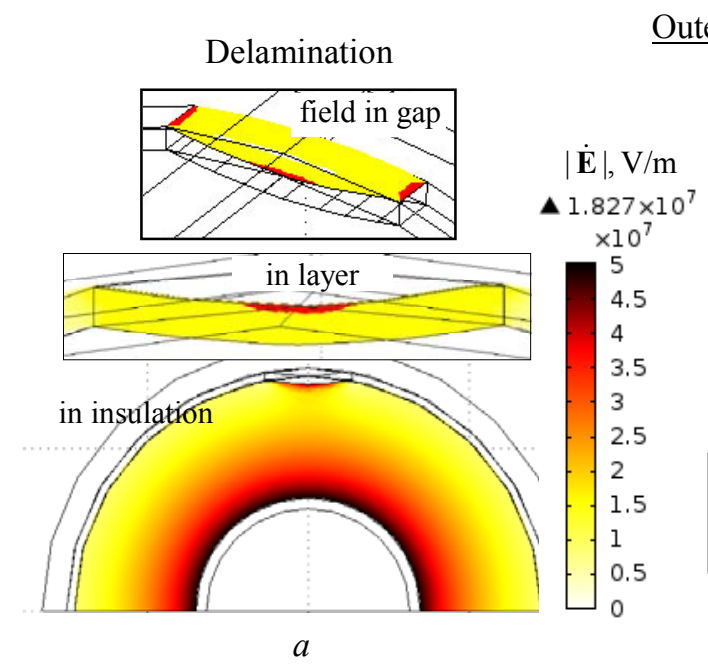

$a$

$\underline{\text { Outer semiconducting layer }}$

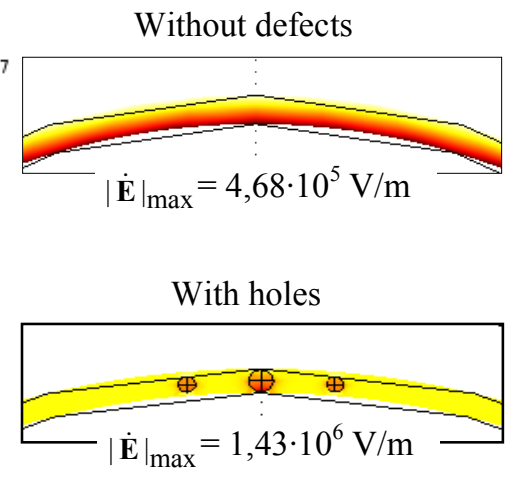

$b$

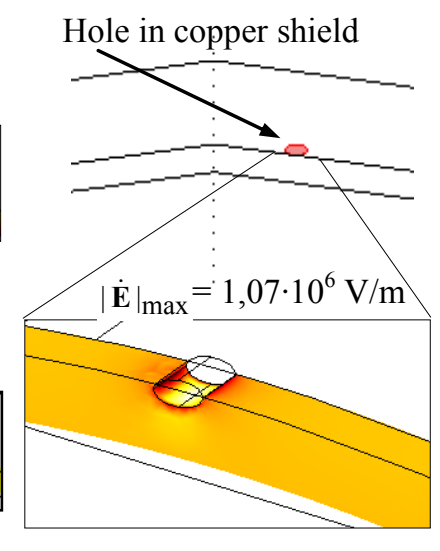

$c$

Fig. 5

Conclusion. The nature of electric field distribution in the multilayer polyethylene insulation of high-voltage power cables is studied allowing for typical cable defects.

As shown by computer modeling, the weak areas in the polyethylene insulation with high electric intensity are formed due to cracks and macroscopic voids-bubbles in the insulation (fig. 3), air gapping, interruption of inner semiconducting layer along the cable conductor and sharp protrusions of the layer into the insulation (fig. 4). These defects are able to interact with each other (fig. 3 at the right), tend to reduce the dielectric strength of the insulating material and lead to its degradation.

The delamination of outer semiconducting layer from the cable copper shield gives rise to electric field enhancement around the layer separation and at the contact of the delaminated layer with the insulation (fig. 5,a). The holes inside the semiconducting layer and air gap in the cable shield owing to its corrosion during the cable operation modify the electric field configuration in the layer and have no direct influence on the field distribution in the insulation. Nevertheless, in the course of long time they may affect on the field in the cable insulation.

The paper confirms the importance of low presence of defects in the cable structure with a view to prevent local electric field enhancement in the polyethylene insulation and, as a consequence, its accelerated ageing. The attained numerical results determine the cable degradation mechanisms as well as the causes of the insulation deterioration and eventual failure. The results are of practical interest because of wide application of cross-linked polyethylene-insulated power cables.

1. Comsol multiphysics modeling and simulation software - http://www.comsol.com/

2. Dissado L.A., Fothergill J.C. Electrical degradation and breakdown in polymers. - London: Peter Peregrinus Ltd. for IEE, 1992. $-601 \mathrm{p}$.

3. Hampton N. HV and EHV cable system aging and testing issues. Chapter 3. - University System of Georgia, Institute of Technology NEETRAC - National Electric Energy Testing, Research and Application Center. - Georgia Tech Research Corporation, February 2016. - 19 p. - http://www.cdfi.gatech.edu/publications/3-HV-Issues-7_withCopyright.pdf

4. Hampton N., Hartlein R., Lennartsson H., Orton H., Ramachadran R. Long-life XLPE insulated power cable. - JiCable 2007. - http://www.neetrac.gatech.edu/publications/jicable07_C_5_1_5.pdf

5. Kucheriava I.M. Coupled electrical and mechanical processes in polyethylene insulation with water tree having branches of complex structure // Tekhnichna Elektrodynamika. - 2016. - No 5. - Pp. 5-10.

6. Podoltsev O.D., Kucheriava I.M. Multiphysics modeling in electrical engineering. - Kyiv: Institute of Electrodynamics of National Academy of Sciences, 2015. - 305 p. (Rus)

7. Podoltsev O.D., Kucheriava I.M. Multiphysics processes in the region of inclusion in polyethylene insulation of power cable (three-dimensional modeling and experiment) // Tekhnichna Elektrodynamika. - 2015. - No 3. Pp. 3-9. (Rus)

8. Power cable failures. - http://www.openelectrical.org/wiki/index.php?title=Power_Cable_Failures

9. Shidlovskij A.K., Shcherba A.A., Zolotarev V.M., Podoltsev O.D., Kucheriava I.M. Extra-high voltage polymeric insulated cables. - Kyiv: Institute of Electrodynamics of National Academy of Sciences, 2013. - 550 p. (Rus)

10. Shuvalov M.Yu., Romashkin A.V., Ovsienko V.L. Analysis of defects in high-voltage power cable insulation by methods of video-microscopy and micro-experiment // Elektrichestvo. - 2000. - No 5. - Pp. 49-57. (Rus)

11. Weedy B.M. High-voltage cable lines. - Moskva: Energoatomizdat,1983. - 232 p. (Rus) 
УДК 621.315.2: 004.94

ДЕФЕКТИ СИЛОВИХ КАБЕЛІВ ТА ЇХНІЙ ВПЛИВ НА РОЗПОДІЛ ЕЛЕКТРИЧНОГО ПОЛЯ В ПОЛІЕТИЛЕНОВІЙ ІЗОЛЯЦІї

Кучерява I.М., докт.техн.наук

Інститут електродинаміки НАН України,

пр. Перемоги, 56, Київ, 03057, Україна. $\quad$ E-mail: rb.irinan@gmail.com

Виконується комп'ютерне моделювання електричного поля в поліетиленовій ізоляиії силових кабелів з характерними дефектами на макрорівні - тріщиною та численними повітряними порожнинами в основній ізоляції, виступом напівпровідного шару по жилі, його нещільним приляганням до ізолячії і перериванням вздовж жили, пустотами в зовнішньому напівпровідному шарі, його відшаруванням від мідного екрана, а також повітряним проміжком у мідному екрані, пов'язаним з корозією матеріалу. Тривимірне моделювання та дослідження електричного поля проводяться в об'ємі кабеля, щзо містить виділену невелику область з дефектами. Показано характер розподілу поля і його посилення в зоні розташування структурних дефектів кабеля та вплив дефектів на розподіл поля в основній ізоляції. Бібл. 11, рис. 5.

Ключові слова: поліетиленова ізоляція, структурні дефекти, локальне посилення електричного поля, тривимірне комп'ютерне моделювання.

УДК 621.315.2: 004.94

ДЕФЕКТЫ СИЛОВЫХ КАБЕЛЕЙ И ИХ ВЛИЯНИЕ НА РАСПРЕДЕЛЕНИЕ ЭЛЕКТРИЧЕСКОГО ПОЛЯ В ПОЛИЭТИЛЕНОВОЙ ИЗОЛЯЦИИ

Кучерявая И.Н., докт.техн.наук

Институт электродинамики НАН Украины, пр. Победы, 56, Киев, 03057, Украина. E-mail: rb.irinan@gmail.com

Выполняется компьютерное моделирование электрического поля в полиэтиленовой изоляции силовых кабелей с типичными дефектами на макроуровне - трещчиной и многочисленными воздушными полостями в основной изоляции, выступом полупроводящчего слоя по жиле, его неплотным прилеганием к изоляциии и прерыванием вдоль жиль, пустотами во внешнем полупроводящем слое, отслоением его от медного экрана, а также воздушным промежутком в медном экране, связанным с коррозией материала. Трехмерное моделирование и исследование электрического поля проводятся в объеме кабеля, включающем выделенную малую областью с дефектами. Показаны характер распределения поля и его усиление в зоне расположения структурных дефектов кабеля и влияние дефектов на распределение поля в основной изоляции. Библ. 11, рис. 5.

Ключевые слова: полиэтиленовая изоляция, структурные дефекты, локальное усиление электрического поля, трехмерное компьютерное моделирование.

1. Comsol multiphysics modeling and simulation software - http://www.comsol.com/

2. Dissado L.A., Fothergill J.C. Electrical degradation and breakdown in polymers. - London: Peter Peregrinus Ltd. for IEE, 1992. $-601 \mathrm{p}$.

3. Hampton N. HV and EHV cable system aging and testing issues. Chapter 3. - University System of Georgia, Institute of Technology NEETRAC - National Electric Energy Testing, Research and Application Center. - Georgia Tech Research Corporation, February 2016. - 19 p. - http://www.cdfi.gatech.edu/publications/3-HV-Issues-7_withCopyright.pdf

4. Hampton N., Hartlein R., Lennartsson H., Orton H., Ramachadran R. Long-life XLPE insulated power cable. - JiCable 2007. - http://www.neetrac.gatech.edu/publications/jicable07_C_5_1_5.pdf

5. Kucheriava I.M. Coupled electrical and mechanical processes in polyethylene insulation with water tree having branches of complex structure // Tekhnichna Elektrodynamika. - 2016. - № 5. - Pp. 5-10.

6. Подольиев А.Д., Кучерявая И.Н. Мультифизические процессы в области включения в полиэтиленовой изоляции силового кабеля (трехмерное моделирование и эксперимент) // Технічна електродинаміка. - 2015. № 3. - C. 3-9.

7. Подольцев А.Д., Кучерявая И.Н. Мультифизическое моделирование в электротехнике. - К.: Ин-т электродинамики НАН Украины, 2015. - 305 с.

8. Power cable failures. - http://www.openelectrical.org/wiki/index.php?title=Power_Cable_Failures

9. Шидловский А.К., Щерба А.А., Золотарев В.М., Подольцев А.Д., Кучерявая И.Н. Кабели с полимерной изоляцией на сверхвысокие напряжения. - К.: Ин-т электродинамики НАН Украины, 2013. - 550 с.

10. Шувалов М.Ю., Ромашкин А.В., Овсиенко В.Л. Анализ дефектов в изоляции силовых высоковольтных кабелей методами видеомикроскопии и микроэксперимента // Электричество. - 2000. - № 5. - С. $49-57$.

11. Уиди Б. Кабельные линии высокого напряжения. - М.: Энергоатомиздат, 1983. - 232 с. 